\title{
THE DETERMINATION OF REDUCING CORTICOIDS
} IN URINE

BY

\author{
IRENE E. BROADBENT, J. P. NEWHOUSE, AND W. KLYNE \\ From the Department of Chemical Pathology, Postgraduate Medical School, London
}

(RECEIVED FOR PUBLICATION MARCH 18, 1953)

During the last few years many chemical methods have been described for the estimation of corticosteroid-like (corticoid) substances in urine (for reviews see Callow, 1950; Lieberman and Dobriner, 1951 ; Robinson and Warren, 1951; Samuels and Reich, 1952). The simpler methods depend on the reducing properties of the $\alpha$-ketol side-chain $\left(\mathrm{CO}^{\left.-\mathrm{CH}_{2} \mathrm{OH}\right)}\right.$ at $\mathrm{C}-17$. Other more elaborate methods involve liberation of formaldehyde from the side-chain by periodic acid, or a colour reaction with phenylhydrazine in the presence of sulphuric acid (Porter and Silber, 1950 ; Carroll, McAlpine, and Noble, 1951). A most promising method recently described by Norymberski (1952) involves oxidation of the sidechain with sodium bismuthate; this has the great advantage that it can be done without previous hydrolysis of the conjugates.

Methods depending on the reducing properties of the side-chain are open to the objection that these properties are non-specific. They are, however, simpler than most of the other methods available, and thus more suitable for use in routine laboratories ; we therefore feel that it is worth putting on record a method which has been developed here over the past four years.

Our earlier work was based on that of Robinson and Norton (1951), who used a semi-automatic urine extractor in conjunction with a copper reduction reaction similar to that of Talbot, Saltzman, Wixom, and Wolfe (1945). (We are greatly indebted to Dr. Alice M. Robinson, St. Bartholomew's Hospital, London, for providing us with details of this method before publication.) An extractor avoids the tedious centrifuging of chloroform-urine emulsions and a fully automatic extractor, more rapid than the original apparatus of Robinson and Warren (1948; cf. Robinson and Norton, 1951), was devised (see Appendix). The extractor has been described briefly elsewhere (Newhouse and Klyne, 1950).

\section{The Copper Reduction Method}

The reproducibility of the copper reduction method used by Robinson and Norton was not entirely satisfactory in our hands and many of the $\stackrel{\circ}{\stackrel{2}{\circ}}$ reaction conditions were varied in attempts to makeo the method more reproducible.

(1) Solvents of differing solubility and volatility, $\dot{\omega}$ methanol, ethanol, $n$-propanol, dioxan, ethylene\& glycol monomethyl ether, were added to the mix-o ture of the copper reagent and extract to help the sparingly soluble corticoid material to dissolve ; the first two solvents proved the best. (2) Variouso copper reagents, including those of Nelson (1944), क् Somogyi $(1945,1950)$, and Harding and Downs $\vec{C}$ (1933), were tried; the last two were the mosto reliable. (3) Different molybdate reagents, e.g. ${ }^{\circ}$ those of Folin and Wu (1920), Benedict (1931), and Nelson (1944), were tried. The most satisfactory change made was in the use of a mixture of equalo volumes of the Folin-Wu phosphomolybdate re-产

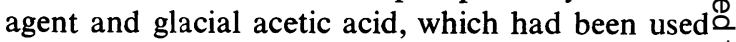
by Heard and Sobel (1946) for a different purpose. $\overrightarrow{0}$ When added in bulk to copper reaction mixtures 3 after heating it prevented turbidity, and increased and stabilized the colour produced because of its: high acetic acid content (cf. Lehmann and Silk, 1952).

Agreement among replicates in the colour reaction was better but still not satisfactory, sinceo erratic variation persisted with many urines. This method worked very well with substances mod-음 erately or very soluble in water (coefficient of vari- $\rightarrow$ ation between replicates for urine extracts, $4.1 \% ;$ for glucose, $1.5 \%$ ), but precision was less good with poorly soluble alkali-labile steroids (coefficient of variation for deoxycorticosterone acetate $6.1 \%$; స for cortisone $8.0 \%$ ). The insolubility, and espe- $\omega$ cially the instability to alkali, of corticoids may< limit the use of alkaline copper reagents in theire measurement. This method was used in part too assess the performance of the extractor (see Appen dix).

\section{The Ferricyanide Titrimetric Method}

Hemphill and Reiss (1947) used the blood sugar $\frac{\overrightarrow{\mathbb{D}}}{\Omega}$ method of Hagedorn and Jensen (1923a and b) to으 determine reducing corticoid material in blood 
Reiss, Hemphill, Gordon, and Cook (1949) applied a similar method to urine, but give few details of their procedure. Gordon and Pelly (1951) have reported satisfactory results for deoxycorticosterone and deoxycorticosterone acetate employing the Hagedorn and Jensen (1923a and b) reaction but estimating colorimetrically the potassium ferrocyanide produced.

We have found that a slight modification of the micro blood-sugar method of Rappaport and Pistiner (1934) gives reproducible results in estimating reducing corticoids of urine. The test sample is heated with a buffered solution of potassium ferricyanide and the excess ferricyanide estimated by iodimetric titration.

We have emp'oyed the conditions suggested by Robinson and Norton (1951) for hydrolysis of conjugates ( 24 hours at $p \mathrm{H} 1$ at room temperature). This is an arbitrary choice since, as pointed out by Marrian (1951), no single procedure liberates all of the reducing corticoids in urine, and it is known (cf. Corcoran, Page, and Dustan, 1950 ; Cox and Marrian, 1951) that much higher yields of formaldehydogenic steroid are obtained by glucuronidase hydrolysis. However, the enzymic methods are very expensive and the simpler and cheaper acid hydrolysis will probably be used in much routine work.

The term "reducing corticoid" is used for the material estimated in our method, following the valuable suggestions of Corcoran (1951) about the nomenclature of urinary materials of probable adrenocortical origin.

\section{Experimental}

Reagents.-The following were used.

1. Chloroform (B.P.) redistilled.

2. Sulphuric acid, $33 \%(\mathrm{v} / \mathrm{v})(12 \mathrm{~N})$.

3. Potassium ferricyanide, $1.80 \mathrm{~g}$. in $1,000 \mathrm{ml}$. water.

4. Dipotassium hydrogen phosphate $\left(\mathrm{K}_{2} \mathrm{HPO}_{4}\right.$, 21.0 g.) and potassium phosphate (tribasic) $\left(\mathrm{K}_{3} \mathrm{PO}_{4}\right.$, $63.8 \mathrm{~g}$.) in $1,000 \mathrm{ml}$. water.

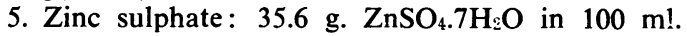
water ( $\equiv 20 \% \mathrm{ZnSO}_{4}$ ).

6. Potassium iodide: a $3 \%$ solution in $20 \% \mathrm{ZnSO}_{4}$ is freshly prepared for each set of titrations.

7. Phosphoric acid: $20 \mathrm{ml}$. of sp. gr. 1.75 made up to $100 \mathrm{ml}$. with water.

8. Sodium hydroxide, $2 \mathrm{~N}$ and $0.1 \mathrm{~N}$ solutions.

9. Sodium thiosulphate: stock solution $(0.1 \mathrm{~N})$ diluted to $0.002 \mathrm{~N}$, containing $6 \mathrm{ml} .2 \mathrm{~N}$ sodium hydroxide/ $1,000 \mathrm{ml}$.

10. Starch, $1 \%$ solution freshly prepared for each set of titrations.

11. Ethanol (Distillers Company Ltd., grade RR).

12. Deoxycorticosterone acetate (D.O.C.A.) standard solutions in ethanol, $50 \mu \mathrm{g}$. and $100 \mu \mathrm{g} . / \mathrm{ml}$.

\section{Method}

Collection and Storage.-A 24-hour collection of urine, without preservative, is stored at $4^{\circ} \mathrm{C}$. until required. The estimation should be carried out as soon as possible.

Extraction.-When the volume of the 24-hour collection is less than $1,500 \mathrm{ml}$. the volume is made up to this figure. The urine is adjusted to $p \mathrm{H} 1$ (B.D.H. 0.5 indicator), using $33 \%$ sulphuric acid, and allowed to stand at room temperature for 24 hours (cf. Robinson and Norton, 1951). (The corticoid level is not appreciably affected by varying the time between 24 and 30 hours.) The lipids are extracted from $100 \mathrm{ml}$. of filtered urine by means of the continuous liquidliquid extractor (see Appendix) with $50 \mathrm{ml}$. of redistilled chloroform for $\mathbf{3 0}$ minutes.

Washing.-This stage largely follows the method of Robinson and Norton (1951). The chloroform extract is washed with $5 \mathrm{ml}$. of distilled water (to remove basic impurities which may be present in the chloroform as their salts), then with three 5 -ml. portions of $0.1 \mathrm{~N}$ sodium hydroxide and finally with three 5 -ml. portions of distilled water. The last washing should be neutral to litmus. All seven aqueous washings are ice-cold and each is back extracted with $5 \mathrm{ml}$. chloroform, which is added to the bulk of the chloroform extract.

Concentration of Extract.-The chloroform extract is evaporated under reduced pressure (approximately $15 \mathrm{~mm}$.) on a water-bath at or below $50^{\circ} \mathrm{C}$. The residue is dissolved in $5 \mathrm{ml}$. ethanol, which is then evaporated off as before.

Estimation of Reducing Substances in the Extract.The dry extract is dissolved in $4 \mathrm{ml}$. ethanol and duplicate 1-ml. portions of this solution are used for the determination. Duplicate blanks $(1 \mathrm{ml}$. ethanol) and duplicate standards are determined in each titration run. The ethanolic solution or ethanol blank (1 ml.) is transferred to a test-tube of standard dimensions $(15 \times 1.5 \mathrm{~cm}$.) to ensure uniform conditions of heating. Equal volumes of ferricyanide and phosphate buffer solutions are mixed, and $2 \mathrm{ml}$. of the mixture added to each tube; the estimation should then be completed without delay. Water $(4 \mathrm{ml}$.) is added to each tube, the contents mixed, and the tubes supported in a wire basket which is placed in a waterbath just off the boil. The temperature is maintained at $90-95^{\circ} \mathrm{C}$. for 10 minutes and the tubes are then cooled quickly to room temperature $\left(15-20^{\circ} \mathrm{C}\right.$.). To the first tube $1 \mathrm{ml}$. of the potassium iodide-zinc sulphate and $1 \mathrm{ml}$. of $20 \%$ phosphoric acid are added with mixing after each addition. The contents are then titrated with $0.002 \mathrm{~N}$ sodium thiosulphate, $1 \%$ starch solution ( 3 drops) being added as the end-point is approached. The other tubes are then titrated similarly.

The test and standard titration figures are subtracted from the blank titration, and the amount of deoxycorticosterone acetate equivalent to $1 \mathrm{ml}$. of urine extract is calculated. Since the titres are not 
strictly proportional to the D.O.C.A. contents of the standards, it is advisable for accurate work to run one standard containing more reducing corticoid and one containing less than the test sample.

Chloroform Blank.-In order to check reagents, a complete "method-blank" is carried out on each redistilled sample of chloroform by extracting $100 \mathrm{ml}$. water adjusted to $\mathrm{pH} 1$ with $33 \%$ sulphuric acid with $50 \mathrm{ml}$. chloraform, and then proceeding in the ordinary way. The difference between this blank and the ethanol blank has never exceeded $0.04 \mathrm{ml}$. of $0.002 \mathrm{~N}$ thiosulphate ( $\equiv 4 \mu \mathrm{g}$. D.O.C.A.) and is usually less. An appropriate correction is made in the calculation of the results.

Ethanol Blank. - The difference between the ethanol blank titre and the titre obtained when the buffered ferricyanide is titrated directly with thiosulphate is very, small (about $0.15 \mathrm{ml}$. $0.002 \mathrm{~N}$ thiosulphate) and varies little between different samples of ethanol (range, 0.06-0.19).

The method was originally tried using redistilled methanol instead of ethanol as solvent. This was unsatisfactory, since the methanol blank titres usually differed from the direct ferricyanide-thiosulphate titres by about $0.70 \mathrm{ml} .0 .002 \mathrm{~N}$ thiosulphate (for one sample, $1.10 \mathrm{ml}$.).

\section{Results}

Reproducibility.-Since previous work on the copper reduction method had not regularly given reproducible results, much attention was paid to this matter in the ferricyanide method.

The reproducibility of the titrimetric stage of the method has been tested by estimating a number of identical samples in the same titration run (Table I) and by a study of the duplicate estimations made during the whole course of the work (Table II).

The reproducibility of the method as a whole was estimated by extracting a number of urines in duplicate, and then estimating the reducing corti-

TABLE I

VAARIATION BETWEEN RESULTS FOR REPLICATE SAMPLES IN THE SAME TITRATION RUN *

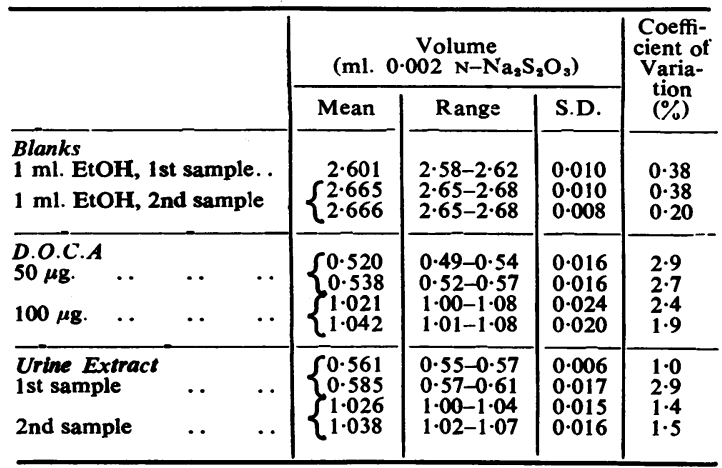

* Number of samples in each run, 12. Values for D.O.C.A. and urine extract in Tables $I$ and II are differences between blank and sample titres.
TABLE II

VARIATION BETWEEN DLPLICATE TITRIMETRIC RESULTS THROUGHOUT THE WORK

\begin{tabular}{|c|c|c|c|c|c|c|}
\hline & \multirow{2}{*}{$\begin{array}{l}\text { Pairs of } \\
\text { Dupli- } \\
\text { cates }\end{array}$} & \multirow{2}{*}{$\begin{array}{l}\text { Mean Vol. } \\
\left(\mathrm{ml}^{0.002 \mathrm{~N}}\right. \\
\left.\mathrm{Na}_{2} \mathrm{~S}_{2} \mathrm{O}_{3}\right)\end{array}$} & \multicolumn{3}{|c|}{$\begin{array}{c}\text { Difference between } \\
\text { Duplicates }(\mathrm{ml} .0 \cdot 002 \\
\left.\mathrm{N}-\mathrm{Na}_{2} \mathrm{~S}_{2} \mathrm{O}_{3}\right)\end{array}$} & \multirow{2}{*}{$\begin{array}{l}\text { Coeffi- } \\
\text { cient of } \\
\text { Varia- } \\
\text { tion }(\%)\end{array}$} \\
\hline & & & Mean & Range & S.D. & \\
\hline Blank $\quad \ldots$ & 64 & $2 \cdot 62$ & 0.011 & $0-0.04$ & 0.016 & 0.6 \\
\hline $\begin{array}{l}\text { D.O.C.A. } \\
(50 \mu \mathrm{g} .) \\
(100 \mu \mathrm{g} .)\end{array}$ & $\begin{array}{l}49 \\
19\end{array}$ & $\begin{array}{l}0.51 \\
0.96\end{array}$ & $\begin{array}{l}0.019 \\
0.031\end{array}$ & $\begin{array}{l}0-0.04 \\
0-0.11\end{array}$ & $\begin{array}{l}0.023 \\
0.044\end{array}$ & $\begin{array}{l}4 \cdot 5 \\
4 \cdot 6\end{array}$ \\
\hline $\begin{array}{l}\text { Urine } \\
\text { tract } \\
25 \mathrm{ml} . \\
\text { urine })\end{array}$ & 86 & 0.60 & 0.018 & $0-0.06$ & 0.024 & $4 \cdot 0$ \\
\hline
\end{tabular}

coids in each extract separately. (In all cases at least two samples of each extract were estimated. Number of urines, 31 ; average quantity of reducing material estimated $\equiv$ approximately $50 \mu \mathrm{g}$. D.O.C.A. $/ 25 \mathrm{ml}$. urine. Differences between duplicate extractions (expressed as $\mu$ g. D.O.C.A. $/ 25 \mathrm{ml}$. urine), mean 1.5 , range $0-7$; root mean square, 2.2 ; coefficient of variation, $4.4 \%$.

In round figures the precision of the method is about $5 \%$; for the copper reduction method in our hands the corresponding figure was about $10 \%$, although some urines gave very discordant duplicates.

Proportionality.-The proportionality between the weight of reducing corticoid and the titre for

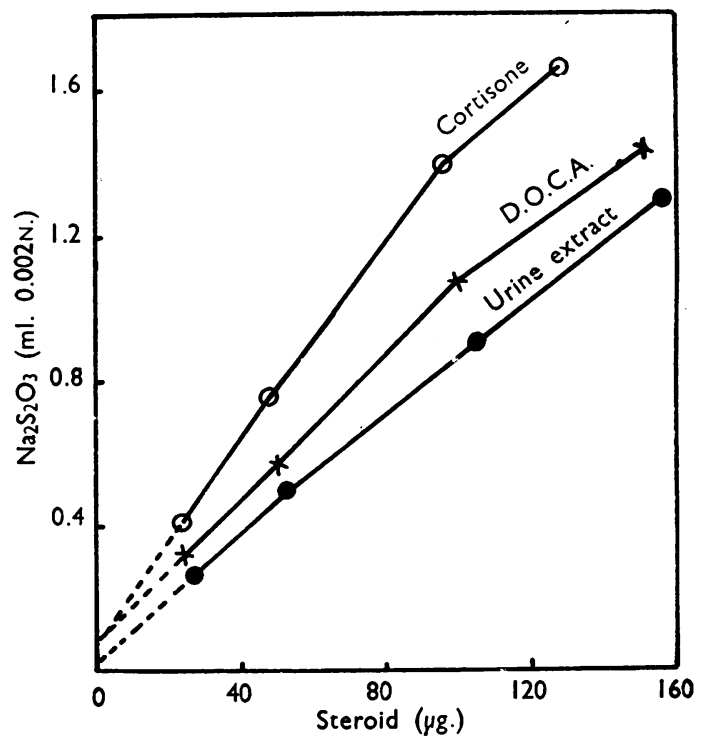

Fig. 1.-Proportionality of thiosulphate titre to quantity of reducing steroids. Time of heating, $10 \mathrm{~min}$. Quantities of reducing steroid in urine extract calculated with reference to a standard containing $50 \mu \mathrm{g}$. D.O.C.A 
D.O.C.A., cortisone, and urine extracts has been investigated (Fig. 1). Curves similar to those shown in Fig. 1 were obtained during the earlier work using ethanol or methanol, and heating for 15 or 20 minutes instead of 10 minutes. It has also been shown that the proportionality is not improved by using a larger excess of ferricyanide.

\section{Recoveries}

Recovery after Partition in Separating Funnels and Washing.-Portions of water $(100 \mathrm{ml}$.) acidified to $p \mathrm{H} 1$ were taken to represent urine. In partition studies, $0.5-3.0 \mathrm{ml}$. of a solution of the reducing corticoid in ethanol or chloroform was added to the acidified water, and this was then extracted in a separating funnel by $45 \mathrm{ml}$. chloroform, the solvent capacity of the extractor. The solvent was washed as usual (p. 191), and the percentage recovery estimated by comparison with a similar but unprocessed corticoid sample (Table III).

\section{TABLE III}

RECOVERY* OF REDUCING CORTICOIDS AFTER PARTITION IN SEPARATING FUNNELS AND WASHING

\begin{tabular}{|c|c|c|c|}
\hline & \multicolumn{3}{|c|}{ Recovery (\%) } \\
\hline & $\begin{array}{l}\text { Deoxycorti- } \\
\text { costerone }\end{array}$ & Cortisone & $\underset{\text { Extract }}{\text { Urine }}$ \\
\hline $\begin{array}{l}\text { Partition and washing } \ldots \\
\text { Washing only } \\
\text { Washing only }\end{array}$ & $\begin{array}{l}96^{*} \\
93^{*} \\
-\end{array}$ & $\begin{array}{l}93^{*} \\
102^{*} \\
95 \dagger\end{array}$ & $\begin{array}{l}65^{*} \\
81^{*} \\
85\end{array}$ \\
\hline
\end{tabular}

* Estimations were made by the titrimetric procedure, except those marked *, in which the colorimetric copper method was used. Percentage recovery values are the mean of at least three sets in each case. Quantities of the reducing corticoids used were 140-200 $\mu \mathrm{g}$. D.O.C.A. or the equivalent except for the cortisone experiment marked $\dagger$, where $150-450 \mu \mathrm{g}$. was used.

Since the nature of the reducing lipid material in urine is unknown, recovery experiments with known cortical steroids (deoxycorticosterone, cortisone, and their acetates) were supplemented by experiments in which the crude lipid extracted from urine was added to water (or urine) and submitted to extraction and washing.

Recovery (Washing Stage Only).-In washing studies, the $0.5-3.0 \mathrm{ml}$. of corticoid solution was added to the $45 \mathrm{ml}$. chloroform after this had been separated from the acidified water as above, and the solution then washed and reducing corticoids determined as usual. In either case, solvent blanks $(0.5-3.0 \mathrm{ml}$. without added corticoid) were put through the same sequence. Percentage recovery values, each the mean of at least three runs, usually agreeing within $5 \%$, are reported in Table III. Over $90 \%$ of crystalline corticosteroid added to water can be recovered after washing. With urine extracts, probably about four-fifths of the urinary corticoid material is removable from acidified water.

Overall Recoveries Using Continuous Extractor. - The overall recovery values for D.O.C.A., cortisone, and extracts of mixed normal urines were determined under the optimal conditions for extraction (see Appendix). The reducing corticoid, dissolved in 1-3 ml. portions of ethanol, was added to $100 \mathrm{ml}$. portions of normal urine that had stood

TABLE IV

OVERALL RECOVERIES* OF REDUCING CORTICOIDS USING CONTINUOUS EXTRACTOR

\begin{tabular}{|c|c|c|c|c|c|c|}
\hline $\begin{array}{c}\text { Experi- } \\
\text { ment } \\
\text { No. }\end{array}$ & $\begin{array}{c}\text { Corticoid } \\
\text { Added }\end{array}$ & 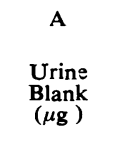 & $\begin{array}{c}\text { B } \\
\text { Urine + } \\
\text { Added } \\
\text { Corticoid } \\
(\mu g .)\end{array}$ & $\begin{array}{c}\text { C } \\
\text { Reco- } \\
\text { vered } \\
\text { Corti- } \\
\text { coid } \\
(\text { B-A) } \\
(\mu \mathrm{g} .)\end{array}$ & $\begin{array}{c}\text { D } \\
\text { Added } \\
\text { Corti- } \\
\text { coid } \\
(\mu \mathrm{g} .)\end{array}$ & $\begin{array}{c}\text { E } \\
\text { Reco- } \\
\text { very } \\
100 \mathrm{C} / \mathrm{D} \\
(\%)\end{array}$ \\
\hline $\begin{array}{l}1 \\
2 \\
3\end{array}$ & D.O.C.A & $\begin{array}{l}231(2,6) \\
276(3,6) \\
276(3,6)\end{array}$ & $\begin{array}{l}353(2,6) \\
400(2,8) \\
650(2,8)\end{array}$ & $\begin{array}{l}122 \\
124 \\
374\end{array}$ & $\begin{array}{l}141 \\
155 \\
465\end{array}$ & $\begin{array}{l}87 \\
80 \\
80\end{array}$ \\
\hline $\begin{array}{l}4 \\
5 \\
6 \\
7\end{array}$ & Cortisone & $\begin{array}{r}148(3,6) \\
148(3,6) \\
33(3,9) \\
114(3,9)\end{array}$ & $\begin{array}{l}265(2,8) \\
517(2,8) \\
180(4,12) \\
607(3,9)\end{array}$ & $\begin{array}{l}117 \\
369 \\
147 \\
493\end{array}$ & $\begin{array}{l}146 \\
439 \\
171 \\
587\end{array}$ & $\begin{array}{l}80 \\
84 \\
86 \\
84\end{array}$ \\
\hline $\begin{array}{r}8 \\
9 \\
10 \\
11 \\
12\end{array}$ & $\begin{array}{l}\text { Urine } \\
\text { extract }\end{array}$ & $\begin{array}{r}169(4,4) \\
232(3,6) \\
185(3,6) \\
185(3,6) \\
40(3,9)\end{array}$ & $\begin{array}{l}289(3,3) \\
456(3,6) \\
269(3,6) \\
429(2,6) \\
232(3,9)\end{array}$ & $\begin{array}{r}120 \\
224 \\
84 \\
244 \\
192\end{array}$ & $\begin{array}{l}200 \\
382 \\
145 \\
434 \\
272\end{array}$ & $\begin{array}{l}60 \\
59 \\
58 \\
56 \\
69\end{array}$ \\
\hline
\end{tabular}

* All recoveries are from urine except for those in experiment 6 , which are recoveries from acidified water. All estimations were made by the titrimetric method, except for experiments 6, 7, and 12, in which the colorimetric copper method was emp'oyed. The results are expressed as $\mu \mathrm{g}$. of the added steroid (urine extract data as $\mu \mathrm{g}$. D.O.C.A.). The figures in parentheses indicate the number of extractions (first figure) and the total number of estimations (second figure), the mean of which is reported.

at $p \mathrm{H} 1.0$ at room temperature for about 24 hours ; the urine was well shaken and extraction, washing, and estimation were performed in the usual way ; 1-2 ml. of ethanol was added to $100 \mathrm{ml}$. samples of the same urine to provide overall recovery blanks. The results are shown in Table IV. If to the mean recovery value for cortisone (80-84\%) some $10 \%$ be added to allow for probable loss in washing, the proportion removed by the extractor would be at least $90 \%$ of that added. This value compares well with the figure for recovery $(93 \%)$ calculated from simple separating funnel partition and washing data for cortisone.

\section{Normal and Pathological Urimes}

Excretion of reducing corticoids for 10 normal men, 10 normal women, and for patients suffering from a variety of conditions which perhaps might be expected to influence adrenal function have been measured. Results are shown in Table $\mathrm{V}$.

Normal values are considerably higher than those obtained by related methods. Robinson and 
TABLE V

EXCRETION OF REDUCING CORTICOIDS BY NORMAL ADULTS AND BY PATIENTS

\begin{tabular}{|c|c|c|c|}
\hline $\begin{array}{l}\text { Sub- } \\
\text { ject }\end{array}$ & Diagnosis & $\begin{array}{l}\text { Reducing } \\
\text { Corticoids } \\
(\mathrm{mg} 24 \mathrm{hr} .)\end{array}$ & $\begin{array}{l}\text { 17-Keto- } \\
\text { steroids } \\
\text { mg. } 24 \mathrm{hr} .)\end{array}$ \\
\hline $1-10$ & Normal males (24-38 yrs.) & $\begin{array}{l}2 \cdot 4 \mathrm{a}, 3 \cdot 2, \dagger \\
3 \cdot 8 \mathrm{a}, 3 \cdot 9 \\
4 \cdot 0,4 \cdot 0 \\
4 \cdot 8 \mathrm{a}, 4 \cdot 9 \\
5 \cdot 5,5 \cdot 9 \\
(\text { Mean } 4 \cdot 2 \text { ) }\end{array}$ & \\
\hline $11-21$ & Normal females ( $22-45$ yrs ) & $\begin{array}{l}2 \cdot 6 \mathrm{a}, 2 \cdot 7 \mathrm{a} \\
2 \cdot 8,3 \cdot 4 \\
3 \cdot 6,3 \cdot 9 \\
4 \cdot 0,4 \cdot 0 \mathrm{a} \\
4 \cdot 1 \mathrm{a}, 4 \cdot 7 \mathrm{a} \\
4 \cdot 8 \\
(\text { Mean } 3 \cdot 7)\end{array}$ & \\
\hline 22 & Myxoedema, F., 63 yrs. & $1 \cdot 9$ & $3 \cdot 1 *$ \\
\hline 23 & $\begin{array}{l}\text { Benign adrenal cortical tumour. } \\
\text { associated with hirsuties and } \\
\text { oligomenorrhea. F. 28 yrs. } \\
\text { (not consecutive days) }\end{array}$ & $\left\{\begin{array}{l}3 \cdot 9 \\
4 \cdot 5 \\
3 \cdot 8\end{array}\right.$ & $\begin{array}{l}46 \cdot 3 \\
38 \cdot 7 \\
41 \cdot 4\end{array}$ \\
\hline 24 & $\begin{array}{l}\text { Cirrhosis of liver with hirsutizs, } \\
\text { F. } 28 \text { yrs. }\end{array}$ & $6 \cdot 1$ & $6 \cdot 4$ \\
\hline 25 & Thyrotoxicosis, M. 49 yrs. & $4 \cdot 2$ & $6 \cdot 2 *$ \\
\hline 26 & Haemochromatosis, M. 71 yrs. & $3 \cdot 9$ & $2 \cdot 1 *$ \\
\hline 27 & Chronic hepatitis, M. 19 yrs. & $5 \cdot 5$ & $5 \cdot 2 *$ \\
\hline 28 & $\begin{array}{l}\text { Malignant hypertension, chronic } \\
\text { unilateral pulmonary tubercu- } \\
\text { losis, M. } 62 \text { yrs. (consecutive } \\
\text { days). }\end{array}$ & $\left\{\begin{array}{l}1 \cdot 7 \\
2 \cdot 2 \\
2 \cdot 1\end{array}\right.$ & $\overline{-}$ \\
\hline 29 & $\begin{array}{l}\text { Rheumatoid arthritis, M. } 38 \text { yrs. } \\
\text { (consecutive days). During } \\
\text { 3rd day patient received } 50 \\
\text { mg A.C.T.H. intravenously. } \\
\text { During } 4 \text { th day patiznt re- } \\
\text { ceived } 80 \mathrm{mg} \text {. A.C.T.H. intra- } \\
\text { venously. }\end{array}$ & $\left\{\begin{array}{l}3 \cdot 5 \\
4 \cdot 1 \\
7 \cdot 7 \\
4 \cdot 0 \\
-\end{array}\right.$ & $\begin{array}{r}9 \cdot 1 \\
9 \cdot 9 \\
14 \cdot 4 \\
22 \cdot 5 \\
17 \cdot 6 \\
9 \cdot 2\end{array}$ \\
\hline 30 & $\begin{array}{l}\text { Acute lymphatic leukaemia, F. } \\
21 \text { yrs. A.C.T.H. ( } 25 \mathrm{mg} \text { in- } \\
\text { travenous drip daily) begin- } \\
\text { ning } 1 \text { hr. before end of } 1 \mathrm{st} \\
\text { day's collection until } 11 \text { Feb. } \\
11,12,13,14,15 \text { Feb. } 1 \cdot 25 \mathrm{mg} \\
\text { A.C.T.H. (intravenous drip) } \\
\text { daily. } 16 \text { Feb-2 Mar. } 25 \mathrm{mg} \\
\text { A.C.T.H. (four times daily, } \\
\text { intramuscularly). }\end{array}$ & $\left\{\begin{array}{lr}7-8 \text { Feb } & 5 \cdot 6 \\
12-13 & 19 \cdot 0 \\
20-21 & 3 \cdot 1 \\
28-29 & 4 \cdot 4\end{array}\right.$ & $\begin{array}{r}1 \cdot 9 \\
28 \cdot 9 \\
6 \cdot 9 \\
\end{array}$ \\
\hline 31 & $\begin{array}{l}\text { Carcinoma of breast with wide- } \\
\text { spread metastases including } \\
\text { adrenals, F. } 57 \text { yrs. (not con- } \\
\text { secutive days!. }\end{array}$ & $\left\{\begin{array}{l}1 \cdot 7 \\
1 \cdot 5 \\
1 \cdot 8\end{array}\right.$ & $\begin{array}{l}7 \cdot 1^{*} \\
5 \cdot 4^{*}\end{array}$ \\
\hline 32 & $\begin{array}{l}\text { Carcinoma of breast with wide- } \\
\text { spread metastases, F. } 51 \text { yrs. }\end{array}$ & $\left\{\begin{array}{l}1 \cdot 7 \\
1 \cdot 7\end{array}\right.$ & $3 \cdot 0$ \\
\hline
\end{tabular}

* In many cases duplicate extractions were made. In all cases at least two determinations of corticoids on the urine extract were carried out. 17-Ketosteroid determinations are included for comparison; these were done by the M.R.C. method (M.R.C. Committee on Clinical Endocrinology, 1951). In all cases except those marked * the 17-ketosteroid and corticoid determinations were done on the same 24-hour urine collection.

† For eight ncr nal persons marked (a) the reducing corticoids were measured after the urine had stood 24 hours at $p \mathrm{H} 7$ as well as by the usual method ( 24 hours at $p H 1)$. The results were (in the order shown above): $0 \cdot 8,1 \cdot 5,1 \cdot 9,1 \cdot 0,2 \cdot 1,1 \cdot 6,2 \cdot 4 \mathrm{mg} / 24 \mathrm{hr}$., i.e., 33, 39, 39, 38, $59,52,39$ and 51 per cent of the va:ue at $p \mathrm{H} 1$.
Norton (1951) found for males, mean, $2.5 \mathrm{mg}$., range $1.2-3.4$ ( + a single value of 5.1$)$; females, mean 2.0 , range, $1.0-3.0 \mathrm{mg}$. (+ single values of 0.5 and 4.8). (These results are for determination without benzene-water partition.)

Heard and Sobel (1946) and Heard and Venning (1946) found values of about 1-2 mg. (means 1.5 and $1.3 \mathrm{mg}$. for males and females respectively). Romanoff, Plager, and Pincus (1949), in a study of diurnal variations in steroid excretion, gave similar values for 24-hour excretions.

As suggested by Robinson and Norton (1951) the conditions in which the excretion of reducing corticoids is grossly abnormal are few. Patients undergoing A.C.T.H. therapy show the expected increase of reducing corticoids.

\section{Summary}

A titrimetric method for determining the reducing corticoids of urine by means of their reaction with ferricyanide is described.

An apparatus for removing lipid material from urine by continuous extraction with a solvent at room temperature has been constructed, and its performance assessed.

We are grateful to the Medical Research Council for a gift of cortisone acetate and to Mr. B. Evans, glassblower, for much skilled and ingenious work in making the extractors.

\section{RFFERENCES}

Benedict, S. R. (1931). J. biol. Chem., 92, 141

Callow, R. K. (1950). In Hormone Assay, ed. Emmens, C. W., p. 384. Academic Press, New York.

Carroll, K. K., McAlpine, H. T., and Noble, R. L. (1951) Canad. med. Ass. J., 65, 363.

Corcoran, A. C. (1951). J. clin. Endocrinol., 11, 445.

Page, I. H., and Dustan, H. P. (1950). J. Lab. clin. Med., 36 297.

Cox, R. I., and Marrian, G. F. (1951). Biochem. J., 48, xxxiii

Folin, O., and $\mathrm{Wu}, \mathrm{H} .(1920)$. J. biol. Chem., 41, 367.

Gordon, J. J., and Pe!ly, J. E. (1951). Nature, Lond, 168, 603.

Hagedorn, H. C., and Jensen, B. N. (1923a, b). Biochem. Z., 135 $46 ; 137,92$.

Harding, V. J., and Downs, C. E. (1933). J. biol. Chem., 101, 487.

Heard, R. D. H., and Sobel, H. (1946). Ibid., 165, 687.

- - and Venning, E. H. (1946). Ibid., 165, 699.

Hemphill, R. E., and Reiss, M. (1947). Endocrinology, 41, 17.

Lehmann, H., and Silk, E. (1952). Biochem. J., 50, xxxi.

Lieberman, S., and Dobriner, K. (1951). Annu. Rev. Biochem., 20, 227.

Marrian, G. F. (1951) J. Endocr., 7, lxix

Medical Research Council Committee on Clinical Endocrinology (1951). Lancet, 2, 585

Ne'son, N. (1944). J. biol. Chem., 153, 375

Newhouse, J. P., and Klyne, W. (1950). Biochem. J., 46, xxiii

Norymberski, J.' K. (1952). Nature, Lond., 170, 1074.

Porter, C. C., and Silber, R. H. (1950). J. biol. Chem., 185, 201.

Rappaport, F., and Pistiner, R. (1934). Mikrochemie, 15, 111

Reiss, M., Hemphill, R. E., Gordon, J. J., and Cook, E. R. (1949) Biochem. J., 44, 632

Robinson, A. M., and Norton, J. M. (1951). J. Endocr., 7, 321

Robinson, A. M., and Norton, J. M. (1951). J. Endocr.
and Warren, F. L. (1948). Biochem. J., 42, xxiii.

- (1951). Rep. Progr. Chem., 48, 297.

Romanoff, L. P., Plager, J., and Pincus, G. (1949). Endocrinology, 45, 10

Samuels, L. T., and Reich, H. (1952). Annu. Rev. Biochem., 21, 129. Somogyi, M. (1945). J. biol. Chem., 160, 61.

- (1950). Private communication.

Talbot, N. B., Saltzman, A. H., Wixom, R. L., and Wolfe, J. K. (1945). J. biol. Chem., 160, 535 . 
A P P E N D I X

\title{
A CONTINUOUS LIQUID-LIQUID EXTRACTOR
}

\author{
BY

\section{J. P. NEWHOUSE}

All methods of determining corticoids depend upon their isolation by extraction with fat solvents such as chloroform or ether. When separating funne's are used for extraction persistent emulsions often develop which must be cleared by centrifugation. Robinson and Warren (1948) designed a liquid-liquid extractor in which urine passes from a separating funnel under gravity down a vertical glass tube bearing four small jets at its lower end, and emerges as a fine spray at the base of a column of chloroform surrounding the inner tube. Since air is excluded, the urine droplets rise through the solvent without emulsifying and their lipid content is partly extracted ; they coalesce in a supernatant layer which is collected via a side-arm in a receiver, from which it is returned manually to the separating funnel for recirculation. Ten such cycles, occupying 50-70 minutes, produce an extract which, after purification, is " sufficient for chemical determination," though complete extraction is not claimed (Robinson and Norton, 1951). The apparatus is semi-automatic, inexpensive, and fairly rapid in operation. In the present work several possibilities of improving its design were investigated. A preliminary communication on the development of the extractor has been made (Newhouse and Klyne, 1950).

\section{Improvements in Extractor Design}

Speed of Operation.-The "turnover" (volume of urine passing through the solvent in 30 minutes) of the Robinson-Warren extractor was much below the minimal rate at which emulsions would develop; any possible increase in the turnover would hasten the extraction of the corticoids by the solvent. The number of jets was therefore increased and the effective heights of both urine and chloroform columns were raised to the maximum consistent with the volumes used $(100 \mathrm{ml}$. and $40 \mathrm{ml}$. respectively). The head of pressure exerted by the urine column was thereby raised from 14 to $25 \mathrm{~cm}$. water and the turnover in 30 minutes was increased from $0.45-0.601$. to 2.71 . The urine thus completed 27 circulations through the solvent in 30 minutes instead of about five as hitherto.

Ease of Operation.-The use of air pressure to circur late urine has been found convenient; the apparatus here described, which was based in part on the soil percolator of Lees $(1947,1948)$, is the most satisfactory one developed (Fig. 1). A siphon tube S leads from the receiver to the separating funnel $F$ via a standard joint stopper FA in the neck of the latter. Urine is drawn upwards by the slight vacuum created in the funnel by a filter pump, and discharged under gravity at the base of the chloroform column CC for re-extraction. No bubbler-tube, as used by Lees, is necessary when air may be safely admitted at the level of the receiver; in one experiment it was shown that aeration of urine does not reduce its corticoid assay level; however, if an inert atmosphere were desired, the stopper which fits loosely over the receiver to silence the noise of air intake and to exclude dust could be replaced by a standard cone bearing a bubbler-tube connected to a nitrogen cylinder or pump.

In Lee's percolator liquid collects during the cycle in the receiver and passes on to the next stage in bulk. In the present apparatus the circulation has been made continuous by minimizing the vacuum exerted and by using a siphon tube of at least $5 \mathrm{~mm}$. inner diameter. When supernatant droplets of urine are drawn up the siphon in a constant stream of air as quickly as they collect, the turnover, and hence the extraction rate, are maximal because the vacuum within the funnel is too slight to resist effectively the downward flow of urine. The apparatus is self-adjusting over a range of low vacua. If too much urine collects in the receiver, the siphon becomes closed; the vacuum then increases until all the urine has been drawn into the funnel; air follows, the vacuum diminishes, and the turnover resumes the normal level.

Uniformity of Performance.-In the RobinsonWarren extractor some urines, especially viscous ones of high protein content, produce a collection of solid particles at the interphase; after a few cycles these hinder the coalescence of the droplets or are carried over to block the jets. This would alter the performance of the apparatus. Furthermore the clearing of the jets after each extraction involves dismantling the whole apparatus. A separate receiver was therefore replaced by a cylindrical glass vessel $\mathbf{R}$, the floor of which was a sintered glass plate, SP (the coarsest and widest available), mounted vertically above the chloroform column CC by a standard joint. Supernatant urine can force its way through the sintered plate, while solid particles are retained. The urine collects in the cylinder $\mathbf{R}$ above and is returned to the separating funnel via the siphon tube S. Since chloroform for charging the column will not flow downward through the filter under gravity, an inlet funnel CT is provided. Chloroform poured into CT can enter the column via two mutually opposed holes in the surface of the socket and cone of the joint; then to close the opening, the holes are separated by a halfturn of the receiver. 


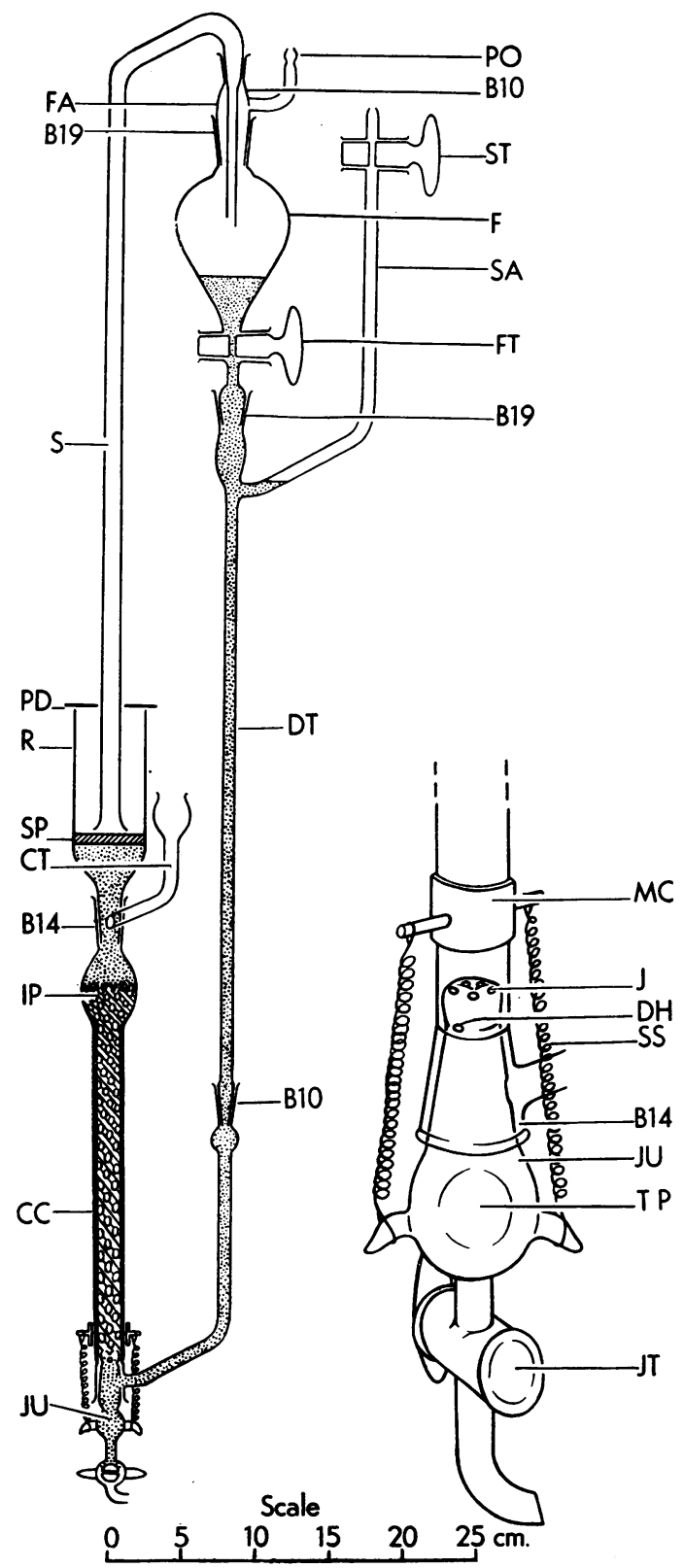

To break emulsions and distribute ascending droplets evenly the inner tube of the Robinson-Warren apparatus bore several bulbs fitting closely inside the chloroform column. The present author found that a wider bulb blown in the outer column at the interphase level (IP), which enables ascending droplets to coalesce freely, was more effective against emulsions than baffles or a spiral series of vanes.

Access to Jets.-A robust and accessible jet unit was made possible by conducting the urine from the sepa-
CC Chloroform column, inner diameter $14 \mathrm{~mm}$., con- $\frac{\vec{P}}{9}$ taining 45-50 ml. chloroform.

CT Chloroform inlet tube.

DH Drain-hole for removal of residual chloroform.

DT Delivery tube, inner diameter $5 \mathrm{~mm}$.

F Separating funnel, capacity $250 \mathrm{ml}$., containing urine. $\vec{\odot}$

FA Funnel adaptor, consisting of B19 cone, Bl0 socket, $\overrightarrow{\vec{\omega}}$ and pump outlet.

FT Separating funnel tap.

IP Interphase between chloroform and urine at level $\omega$ of wider bulb on column.

JT Jet unit tap for removal of chloroform.

JU Jet unit bearing five jet holes (J) of diameter $10-15 / 1,000$ inch, arranged peripherally at the $D$ end of a Bl4 cone.

MC Metal collar.

PD Polythene disc to exclude dust and silence noise of $\overrightarrow{0}$ air intake.

PO Outlet to filter pump.

R Receiver, cylindrical, capacity about $110 \mathrm{ml}$.

S Siphon tube, inner diameter $6 \mathrm{~mm}$., with BI0 coneฏ near upper end.

SA Side äarm.

SP Sintered glass plate, diameter $4 \mathrm{~cm}$., Grade O, pore 3 size $100-150 \mu$

SS Spiral springs.

ST Side-arm tap for expulsion of air bubbles below F.

TP【 Thumb plate.

Dimensions:-J-IP, $23 \mathrm{~cm}$; IP-SP, $10 \mathrm{~cm}$; J-SA (urine surface), $70 \mathrm{~cm}$.

Fig. 1.

rating funnel $F$ to the base of the chloroform column $\frac{0}{\frac{C}{(}}$ CC via an external delivery tube, DT, connected with a standard socket at the bottom of the column. The body of the jet unit, JU, a hollow standard cone, $\bar{O}$ can be inserted from below into this socket and easily $\vec{\Phi}$ removed for cleaning; it is held in place by springs $\stackrel{\rho}{\perp}$ SS attached to a metal collar MC. At its wider $\stackrel{\mathbb{Q}}{\Omega}$ (lower) end, the cone has a tap, JT, for emptying the chloroform from both column and unit. The upper end of the cone terminates in a rounded surface, $O$ 
pierced by five small jets, J ; a larger drainhole, DH, is placed laterally for the removal of chloroform collecting below jet level. Urine from the delivery tube DT enters the unit via a hole perforating the ground surfaces of socket and cone and escapes via the jets into the chloroform.

\section{Operation of the Continuous Extractor}

With JU open to DT, and JT closed, $50 \mathrm{ml}$. of chloroform is poured into column CC via $\mathrm{CT}$; CT and FT are then closed. Filtered urine $(100 \mathrm{ml}$.) is poured into $R$ and drawn up into $F$ by applying suction to PO. FT and ST are then opened so that urine may trickle slowly into DT, thereby forming a layer free from air bubbles above the chloroform. In a few seconds all air has been drawn out from below FT, which is then closed while JU is opened; when the level of urine in SA has fallen below the elbow bend, ST is quickly closed so that the maximal volume of urine may circulate. FT is then opened and the apparatus is run for 30 minutes on a pump pressure of about $5 \mathrm{~mm}$. $\mathrm{Hg}$ below atmospheric pressure. The apparatus needs no attention, provided the pump maintains a suction just sufficient to maintain a steady flow of mixed air and urine up the siphon without its cross-section becoming anywhere full of urine. Too low a vacuum will lead to interrupted operation, while too high a vacuum will reduce turnover by reducing the head of pressure in DT. To remove the extract, JU is turned so as to close the inlet from DT, and the chloroform is slowly run out via JT into a separating funnel for washing. Syrupy orthophosphoric acid, but not petroleum jelly or silicone, serves well as a non-reducing lubricant for joints and taps. The whole apparatus is rinsed between runs with distilled water; the use of an acidic cleaning mixture is advisable following each series of runs.

Since the completion of this design, Cohen (1950) has described a simpler apparatus, also employing air-pressure differences to circulate urine through chloroform for use in steroid determinations. The present apparatus may have other applications in techniques involving solvent extraction at room temperature; where emulsion problems do not arise, the sintered plate could be discarded.

\section{Performance of the Continuous Extractor}

Recovery trials using the extractor have already been described (p. 193). Other aspects of the performance of the extractor were investigated as detailed below using normal pooled acidified urine. The colorimetric copper method was employed to measure reducing material in the extracts; colorimetric readings for triplicate samples varied from the means by up to $10 \%$.

Optimal Conditions of Operating.-The effect of varying the period of extraction of samples of the same urine upon the quantity of corticoid extracted was investigated. The results for individual extractions (in parentheses) and the mean for each set of three are expressed as $\mu$ g. D.O.C.A./ $100 \mathrm{ml}$. urine: 15 minutes: $154(135,169,156)$; 30 minutes: 190 (196, $198,177)$; 60 minutes: $197,(177,202,211)$; 120 minutes: $213(207,219)$.

Since the corticoid value was little increased by extraction for periods greater than 30 minutes, this period of running was adopted in the standard procedure. Replacement of the $50 \mathrm{ml}$. chloroform in the extractor by fresh solvent after 15 minutes raised the assay level slightly (about 15\%); the difference seemed insufficient to justify adopting this measure regularly.

To determine whether incidental aeration of urine during its circulation in the extractor might reduce the level of corticoid determined, filtered air was bubbled for 30 minutes through mixtures of $45 \mathrm{ml}$. chloroform and $100 \mathrm{ml}$. water adjusted to $p \mathrm{H} 1$, to which $0.5 \mathrm{ml}$. of a methanolic solution of neutral urinary lipid had been added. The mixtures were washed and measured as usual; similar mixtures which had not been specially aerated were also put through as controls. The mean value for the aerated material was 68 ( $\mu$ g. D.O.C.A.), for the control material $71 \mu \mathrm{g}$.

Comparison with Other Methods of Urine Extraction.-Portions of the same normal urine $(100 \mathrm{ml}$.) and a total of 45 to $50 \mathrm{ml}$. of chloroform were used in each trial. The Robinson-Warren apparatus was run manually, 10-12 circulations occupying 50-60 minutes. The continuous extractor was operated for 30 minutes. In separating-funnel extractions the urine was extracted by three $15-\mathrm{ml}$. portions of chloroform with centrifugation at 2,000 r.p.m. for 20 minutes between separations to clear emulsions. Each trial included three or four extractions by each method; the extracts were washed, concentrated, and measured colorimetrically in triplicate as usual.

TABLE I

COMPARISON OF METHODS OF EXTRACTION

\begin{tabular}{|c|c|c|c|}
\hline $\begin{array}{l}\text { Experi- } \\
\text { ment }\end{array}$ & $\begin{array}{l}\text { Extraction Methods } \\
\text { Compared }\end{array}$ & $\begin{array}{c}\text { Reducing } \\
\text { Corticoid } \\
(\mu \mathrm{g} . \text { D O C.A. } / \\
100 \mathrm{ml} \text {. } \\
\text { Urine })\end{array}$ & $\begin{array}{l}\text { Value as } \\
\text { Percentage of } \\
\text { that for } \\
\text { Continuous } \\
\text { Extractor }\end{array}$ \\
\hline 1 & $\begin{array}{l}\text { Newhouse } \\
\text { Robinson-Warren }\end{array}$ & $\begin{array}{l}361 \\
346\end{array}$ & $\overline{96}$ \\
\hline 2 & $\begin{array}{l}\text { Newhouse } \\
\text { Robinson-Warren }\end{array}$ & $\begin{array}{l}420 \\
336\end{array}$ & $\overline{79}$ \\
\hline 3 & $\begin{array}{l}\text { Newhouse } \\
\text { Separating funnel }\end{array}$ & $\begin{array}{l}264 \\
244\end{array}$ & $\overline{92}$ \\
\hline
\end{tabular}

Table I indicates that the continuous extractor extracts as much reducing corticoid as the RobinsonWarren apparatus, or more, as in experiment 2, where the urine used tended to block the jets. Its results are comparable with those of separating-funnel extraction, and it occupies less time than either of the other methods.

\section{REFERENCES}

Cohen, S. L. (1950). J. Lab. clin. Med., 36, 769.

Lees, H. (1947). J. agric Sci., 37, 27. - (1948). Biochem. J., 42, xxiii.

Newhouse, J. P., and Klyne, W. (1950). Ibid., 46, xxiii.

Robinson, A. M., and Norton, J. M. (1951). J. Endocrinol., 7, 321. and Warren, F. L. (1948). Biochem. J., 42, xxiii. 